\title{
Osteoma of Temporal Bone-A Rare Case Report
}

\author{
Kartik Parelkar, Vandana Thorawade, Mohan Jagade, Rajesh Kar, Madhavi Pandare, \\ Rajanala Nataraj, Reshma Hanwate, Anoop Attakil, Rohini Kashide \\ Department of ENT, Grant Goverment Medical College \& Sir J.J. Group of Hospitals, Mumbai, India \\ Email: kartikparelkar@ymail.com
}

Received 6 July 2014; revised 3 August 2014; accepted 28 August 2014

Copyright (C) 2014 by authors and Scientific Research Publishing Inc.

This work is licensed under the Creative Commons Attribution International License (CC BY). http://creativecommons.org/licenses/by/4.0/

(c) (i) Open Access

\begin{abstract}
Osteoma is a slow-growing tumor formed by mature bone tissue. In the temporal bone, intracanalicular osteomas are more frequent while extracanalicular ostemoas are rare. They very rarely occur over the mastoid region. They are treated mainly for cosmetic purposes. These are readily excised and recurrence is rare after complete excision. In this case report, we want to revisit this rare mastoid osteoma and discuss the differential diagnosis and treatment. We believe that this report will be of interest to otolaryngologists when dealing with temporal bone osteomas.
\end{abstract}

\section{Keywords}

Osteoma, Mastoid, HRCT Temporal Bone

\section{Introduction}

Temporal bone osteoma is a rare entity [1]. Those located in the mastoid and squamous parts of temporal bone may cause cosmetic deformity such as mastoid mass or an auricular protrusion [2]. In the skull they are commonly located in the fronto-ethmoid region. In differential diagnosis, other neoplasms of mastoid region including exostosis, osteosarcoma and osteoblastic metastasis should be considered [3].

\section{Case Report}

26-year-old female patient came to the outpatient clinic with a progressively enlarging postauricular mass for a duration of 10 years (Figure 1). There was no accompanying symptom of earache, discharge, hearing loss, vertigo or tinnitus. Examination revealed a $4 \times 3 \mathrm{~cm}$ mass on the left mastoid region which was hard and painless.

There was no induration or erythema on the overlying skin. The patient denied previous facial nerve paralysis.

How to cite this paper: Parelkar, K., Thorawade, V., Jagade, M., Kar, R., Pandare, M., Nataraj, R., Hanwate, R., Attakil, A. and Kashide, R. (2014) Osteoma of Temporal Bone-A Rare Case Report. International Journal of Otolaryngology and Head \& Neck Surgery, 3, 252-258. http://dx.doi.org/10.4236/ijohns.2014.35046 
Bilateral tympanic membranes were normal. X-ray of skull lateral view showed a dense radio-opaque mass in mastoid region (Figure 2). HRCT temporal bone indicated a well demarcated, dense, sclerotic mass of $3.9 \times 2.4$ $\mathrm{cm}$ on the posterolateral part of the left mastoid bone (Figure 3). Middle and inner ear were normal and the

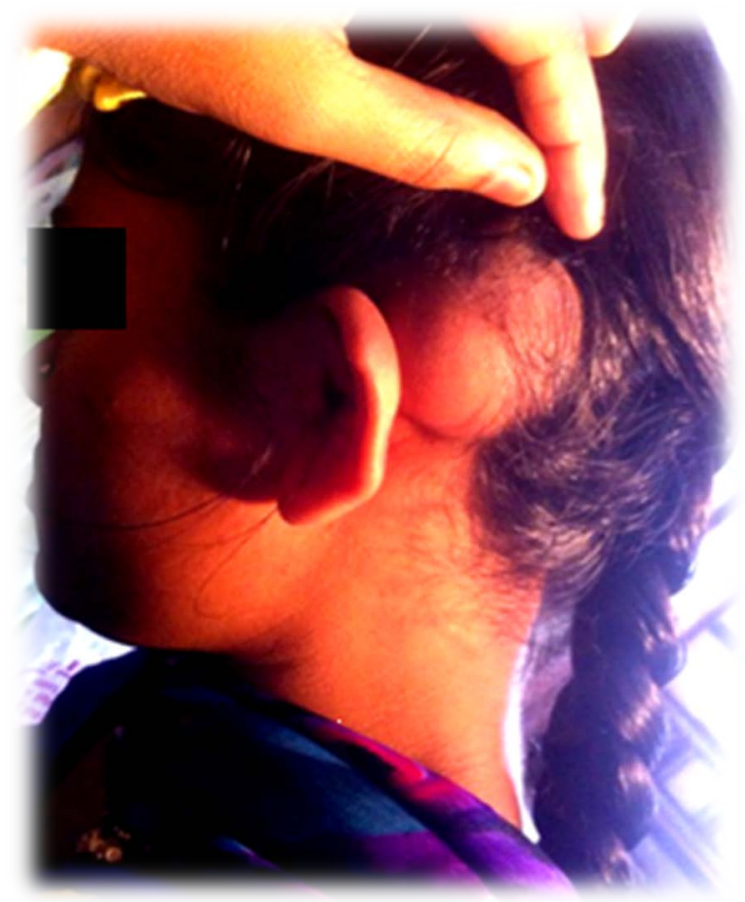

Figure 1. Showing the postauricular osteoma.

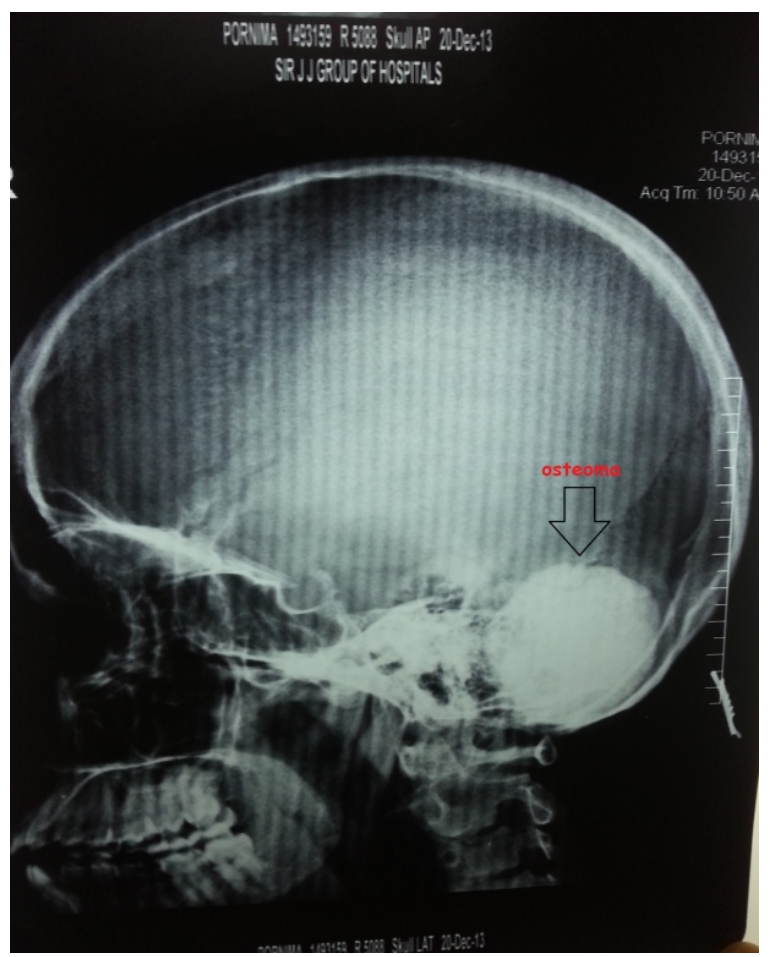

Figure 2. X-ray skull lateral view showing the radio-opaque osteoma. 


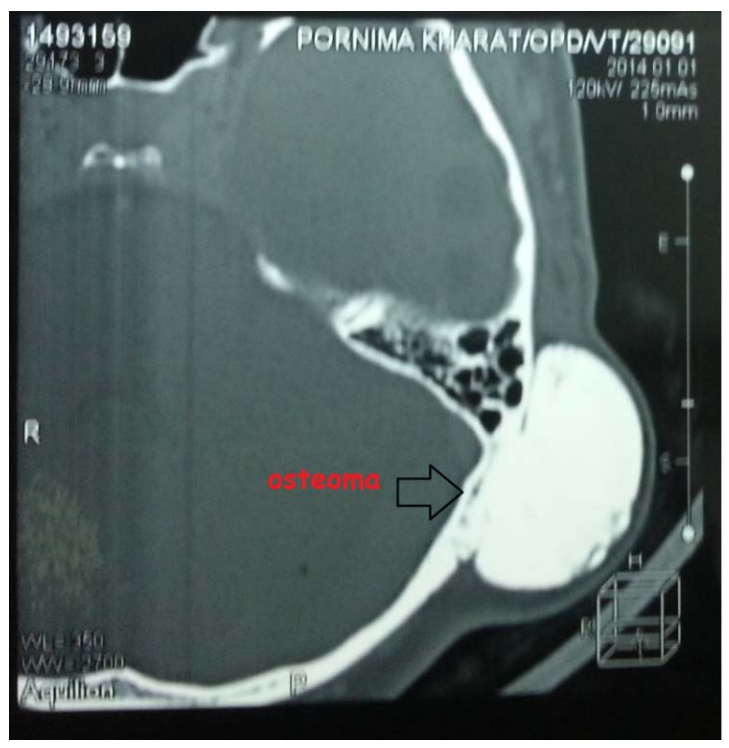

Figure 3. CT scan showing the osseous outgrowth over the left mastoid.

facial nerve was not involved. Patient was posted for local excision of the mass under general anesthesia. A postauricular skin incision and periosteal elevation were performed. The mass was exposed under the periosteum (Figure 4) and removed entirely by using a chisel (Figure 5). The mass had no muscle attachments as such. The base of the lesion (Figure 6) was drilled with a diamond burr under continuous irrigation until normal mastoid bone was identified. Postoperative period was uneventful. The specimen (Figure 7) was sent for histopathological examination which was consistent with osteoma. In the histologic examination varying degrees of osteoblastic and osteoclastic activities showing lamellar bone with fibrovascular bundles were noted (Figure 8) (Hematoxylin and Eosin; original magnification, $\times 10$ ).

\section{Discussion}

Head \& neck osteomas are very rare. According to Dominiguez Perez only 150 cases have been reported in literature in 2010 [4]. Osteomas located in all portions of the temporal bone, including external auditory canal (the most common site), squama, mastoid, middle ear, glenoid fossa, eustachian tube, internal auditory canal, petrous apex and styloid process have been reported [2] [3] [5]-[9]. Mastoid portion is the second most common area for the existence of temporal bone osteomas following the external auditory canal [2].

Histologically there are three types of osteoma of the mastoid: osteoma compactum, osteoma cancellare, and osteoma cartilagineum. Clinically it is difficult to distinguish the type of osteoma because of the similarity of the symptoms and objective signs [10]. Compact osteomas have a wider base and are very slow growing whereas spongy osteomas are more likely to be pedunculated and grow relatively faster.

Trauma, surgery, radiotherapy, chronic infection and pituitary dysfunction are all included in the etiology of mastoid osteomas. However the precise etiology is still unknown and considered to be a true bone tumor [11][14]. According to Haymann it was due to an alteration in the growth of the cranial bones [15]. Freidberg suggested it occurred as a result of trauma followed by periostitis [15]. Middle ear osteoma was diagnosed in two brothers which might indicate genetic etiology [16].

Furthermore it was reported that temporal bone osteomas occur twice as often in females, whereas external auditory canal osteomas occur twice as often in males [17].

At the time of presentation the size of osteoma is generally not bigger than $3 \mathrm{~cm}$ [2] [18]. Superficial osteomas have smooth surface, bony hard in consistency and the overlying skin is not involved [2]. The presented lesion caused cosmetic deformity as a result of gradual growth to the size of approximately $4 \times 3 \mathrm{~cm}$ over 10 years. Clinically mastoid osteomas rarely cause pain or inflammation. Pain occurs when the growth of the lesion involves the inner table of the temporal bone [19]. Pain may be localized in the ear region, the tympanic membrane or in the neck. The latter can be due to the irritation of the greater auricular or small occipital nerves [10]. 


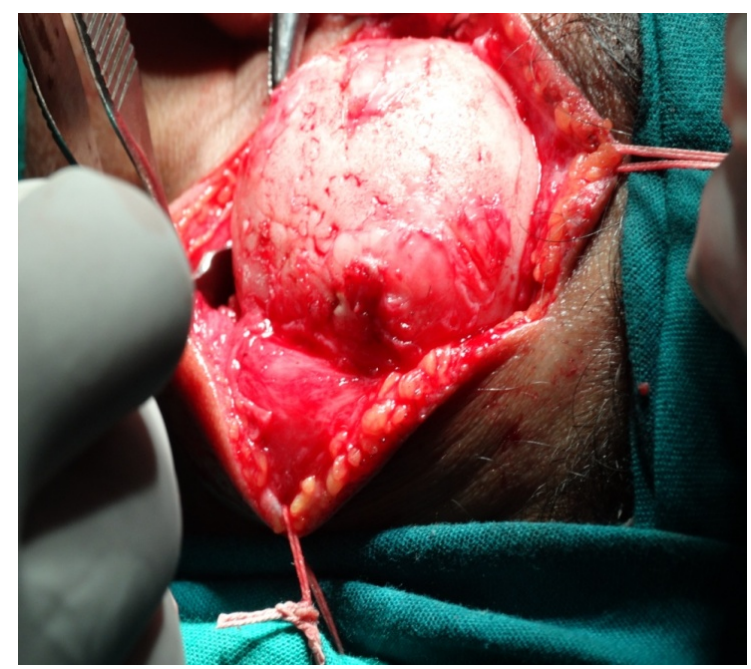

Figure 4. Osteoma on elevation of the periosteum.

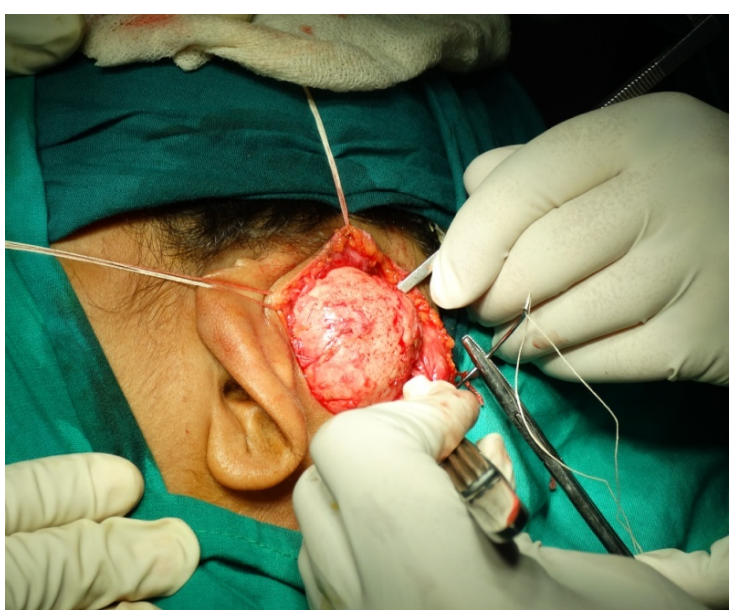

Figure 5. Chisel being used to separate the osteoma from its base.

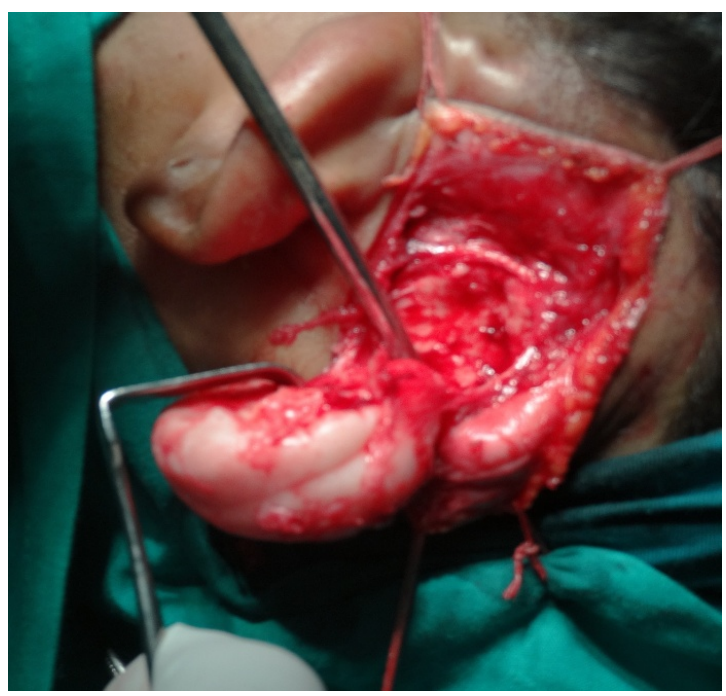

Figure 6. View of the base of the osteoma. 


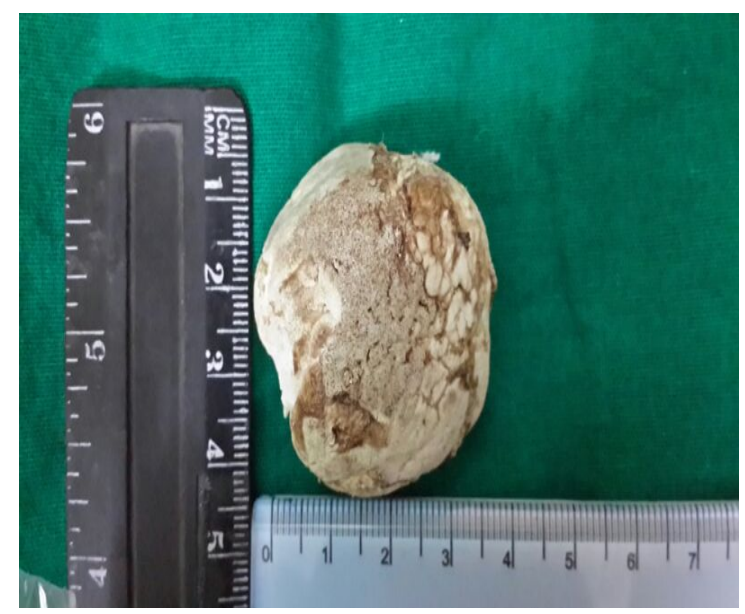

Figure 7. Gross specimen of the osteoma.

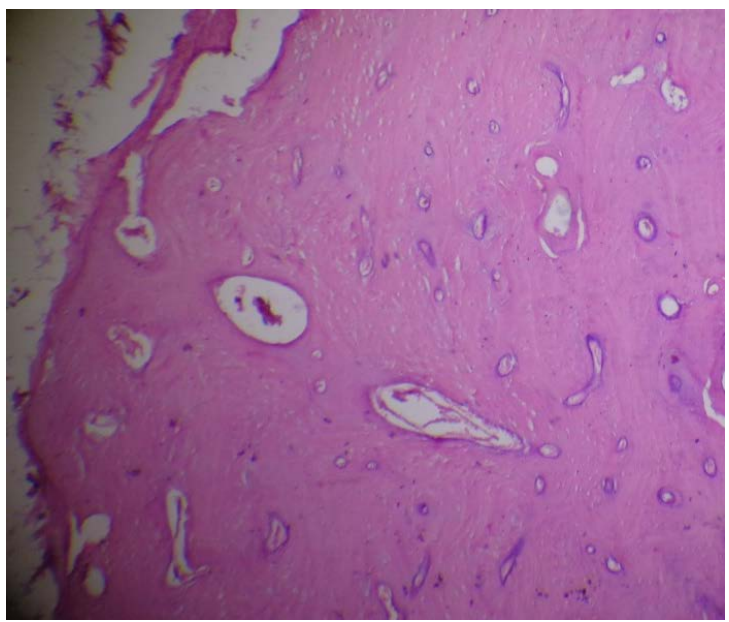

Figure 8. Showing lamellar bone and fibrovascular bundles; H-E STAIN, $\times 10$.

Osteomas can cause functional symptoms. The neoplasm may infiltrate the cortex, causing posterior wall to be pushed forward, resulting in obstruction of the external auditory canal and conductive hearing loss.

Osteomas can arise from the inner table of squamous and petrous part of the temporal bone resulting in brain compression and generalized epileptic seizure [20].

Pressure-induced pain can be referred to the neck, temporomandibular joint or middle ear. In the presence of external ear canal obstruction, conductive hearing loss and chronic suppuration may occur [21] [22]. A mastoid osteoma compressing the posterior fossa structures and causing intracranial complications has been reported by Van Dellen [23].

In differential diagnosis of mastoid osteomas, osteosarcoma; osteoblastic metastasis; isolated eosinophilic granuloma; Paget's disease; giant cell tumor; osteoid osteoma; calcified meningioma and monostotic fibrous dysplasia should be considered. Radiologic borders of these lesions are less clear than those of osteomas [3]. HRCT scan demonstrates an osteoma as well demarcated, dense, sclerotic outgrowth from the mastoid bone. Surgery is indicated for both cosmetic reasons and confirmation of the diagnosis of osteomas of the mastoid and squamous portion of the temporal bone. Exostosis and osteoma are very similar in most aspects however exostosis lacks fibrovascular channels [24]. Also osteomas are bony growths that are single, unilateral and pedunculated and mostly arise from typanomastoid or tympanosquamous suture lines laterally [6] whereas exostoses are multiple, usually bilateral and broad based and are found medial to sutures of the temporal bone [11].

The osteoma must completely be excised until normal mastoid air cells are exposed. These lesions are limited to the external cortex generally hence a cleavage plane is encountered where the osteoma meets the normal bone. 
In mastoid osteomas extending into the bony labyrinth and facial nerve, complete removal might not be indicated since the damage to these structures is likely. Recurrence is rare [2] [21].

Tumours involving middle ear and inner ear are small and tend to remain small so observation is preferred unless symptomatic. When there is functional disorder like hearing loss or vertigo judicious surgical removal maybe undertaken. Surgical management of internal auditory canal osteoma is varied. Both middle cranial fossa approach and suboccipital approach have been employed [25]. Approach generally depends on location, size, preference and experience of the surgeon.

Gardners syndrome must be kept in mind in cases of multiple osteomas. Gardner's syndrome is characterized by multiple intestinal polyps, epidermoid inclusion cysts, fibromas of the skin and mesentery and osteomas. Osteomas in Gardner's syndrome have a predilection for membranous bones and the mandible and maxilla are more commonly involved [26].

\section{Conclusion}

Osteoma of temporal bone over mastoid area is a very rare tumor. HRCT temporal bone eliminates the main differentials and guides in management of osteomas by visualising tumour extension. Treatment is surgical and must be considered according to the cosmetic deformity and the symptoms.

\section{References}

[1] Unal, O.F., Tosun, F., Yetiser, S. and Dundar, A. (2000) Osteoma of the Middle Ear. International Journal of Pediatric Otorhinolaryngology, 52, 193-195. http://dx.doi.org/10.1016/S0165-5876(00)00286-X

[2] Denia, A., Perez, F., Canalis, R.R., et al. (1979) Extracanalicular Osteomas of the Temporal Bone. ACTA Oto-Laryngologica, 105, 706-709. http://dx.doi.org/10.1001/archotol.1979.00790240020005

[3] Estrem, S.A., Vessely, M.B. and Oro, J.J. (1993) Osteoma of the Internal Auditory Canal. Otolaryngology, Head and Neck Surgery, 108, 293-297.

[4] Pérez, Á.D.D., Romero, R.R., Durán, D.E., Montaño, P.R., Bernal, R.A. and Rodríguez, C.M. (2011) El osteoma en la mastoides, ¿un hallazgo incidental? Acta Otorrinolaringológica Española, 62, 140-143. http://dx.doi.org/10.1001/archotol.1940.00660010852006

[5] Burton, D.M. and Gonzalez, C. (1991) Mastoid Osteomas. Ear, Nose Throat Journal, 70, 161-162.

[6] Yamasoba, T., Harada, T., Okuno, T., et al. (1990) Osteoma of the Middle Ear. Report of a Case. Archives of Otolaryngology_Head and Neck Surgery, 116, 1214-1216. http://dx.doi.org/10.1001/archotol.1990.01870100108025

[7] D’Ottovai, L.R., Piccirillo, E., De Sanctis, S., et al. (1997) Mastoid Osteomas: Review of the Literature and Presentation of Two Clinical Cases. Acta Otorhinolaryngologica Italica, 17, 136-139.

[8] Gungor, A., Cincik, H., Poyrazoglu, E., Saglam, O. and Candan, H. (2004) Mastoid Osteomas: Report of Two Cases. Otology Neurotology, 25, 95-97. http://dx.doi.org/10.1097/00129492-200403000-00002

[9] Birrell, J.F. (1978) Osteoma of the Mastoid. Journal of the Royal College of Surgeons of Edinburgh, 23, 305-309.

[10] Cinelli, A.A. (1941) Osteoma Eburneum of the Mastoid. Archives of Otolaryngology, Head and Neck Surgery, 33, 421-424. http://dx.doi.org/10.1001/archotol.1941.00660030425008

[11] Fenton, J.E., Turner, J. and Fagan, P.A. (1996) A Histopathologic Review of Temporal Bone Exostoses and Osteomata. Laryngoscope, 106, 624-628. http://dx.doi.org/10.1097/00005537-199605000-00020

[12] Graham, M.D. (1979) Osteomas and Exostoses of the External Auditory Canal. Journal of Otolaryngology, 88, 566572.

[13] Tran, L.P., Grungfast, K.M. and Selesnick, S.H. (1996) Benign Lesions of the External Auditory Canal. Otolaryngologic Clinics of North America, 29, 807-825.

[14] Fisher, E.W. and McManus, T.C. (1994) Surgery of the External Auditory Canal Exostoses and Osteomata. The Journal of Laryngology \& Otology, 108, 106-110. http://dx.doi.org/10.1017/S0022215100126027

[15] Friedberg, S.A. (1938) Osteoma of Mastoid Process. Archives of Otolaryngology, Head and Neck Surgery, 28, 20-26. http://dx.doi.org/10.1001/archotol.1938.00650040027003

[16] Thomas, R. (1964) Familial Osteoma of the Middle Ear. The Journal of Laryngology \& Otology, 78, 805-807. http://dx.doi.org/10.1017/S0022215100062794

[17] Ohhashi, M., Terayama, Y. and Mitsui, H. (1984) Osteoma of the Temporal Bone: A Case Report. Nippon Jibiinkoka Gakkai Kaiho, 87, 590-595. http://dx.doi.org/10.3950/jibiinkoka.87.590

[18] Guerin, N., Chauveau, E., Julien, M., Dumont, J.M. and Merignargues, G. (1996) Osteoma of the Mastoid Bone: Re- 
port of Two Cases. Annals of Otology, Rhinology, and Laryngology, 117, 127-132.

[19] Stuart, E.A. (1940) Osteoma of the Mastoid: Report of a Case with Investigations of the Constitutional Background. Archives of Otolaryngology, Head and Neck Surgery, 31, 838-854. http://dx.doi.org/10.1001/archotol.1940.00660010852006

[20] Bhandari, Y.S. and Jones, R.A.C. (1972) Osteoma of the Middle Cranial Fossa. Journal of Neurosurgery, 37, 610-612. http://dx.doi.org/10.3171/jns.1972.37.5.0610

[21] Probst, L.E., Shankar, L. and Fox, R. (1991) Osteoma of the Mastoid Bone. Journal of Otolaryngology, 20, $228-230$.

[22] Singh, I., Sanasam, J.C., Bhatia, P.L. and Singh, L.S. (1979) Giant Osteoma of the Mastoid. Ear, Nose and Throat Disorders, 58, 243-245.

[23] Van Dellen, J.R. (1977) A Mastoid Osteoma Causing Intracranial Complications: A Case Report. The South African Medical Journal, 51, 597-598.

[24] Sheehy, J.J. (1982) Diffuse Exostoses and Osteomata of the External Auditory Canal: A Report of 100 Cases. Otolaryngology, Head and Neck Surgery, 90, 337-342.

[25] Clerico, D.M., Jahn, A.F. and Fontanella, S. (1994) Osteoma of the Internalauditory Canal. Case Report and Literature Review. Annals of Otology, Rhinology, and Laryngology, 103, 9-23.

[26] Smud, D., Augustin, G., Kekez, T., Kinda, E., Majerovic, M. and Jelincic, Z. (2007) Gardner’s Syndrome: Genetic Testing and Colonoscopy Are Indicated in Adolescents and Young Adults with Cranial Osteomas: A Case Report. World Journal of Gastroenterology, 13, 3900-3903 
Scientific Research Publishing (SCIRP) is one of the largest Open Access journal publishers. It is currently publishing more than 200 open access, online, peer-reviewed journals covering a wide range of academic disciplines. SCIRP serves the worldwide academic communities and contributes to the progress and application of science with its publication.

Other selected journals from SCIRP are listed as below. Submit your manuscript to us via either submit@scirp.org or Online Submission Portal.
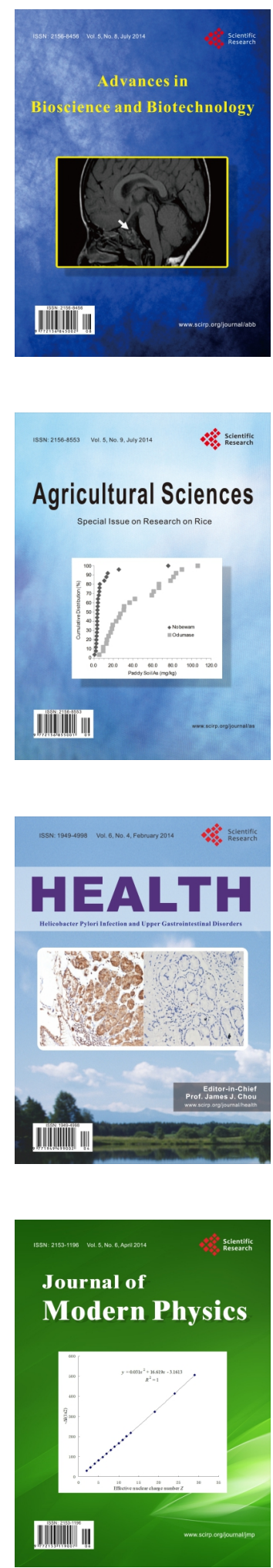
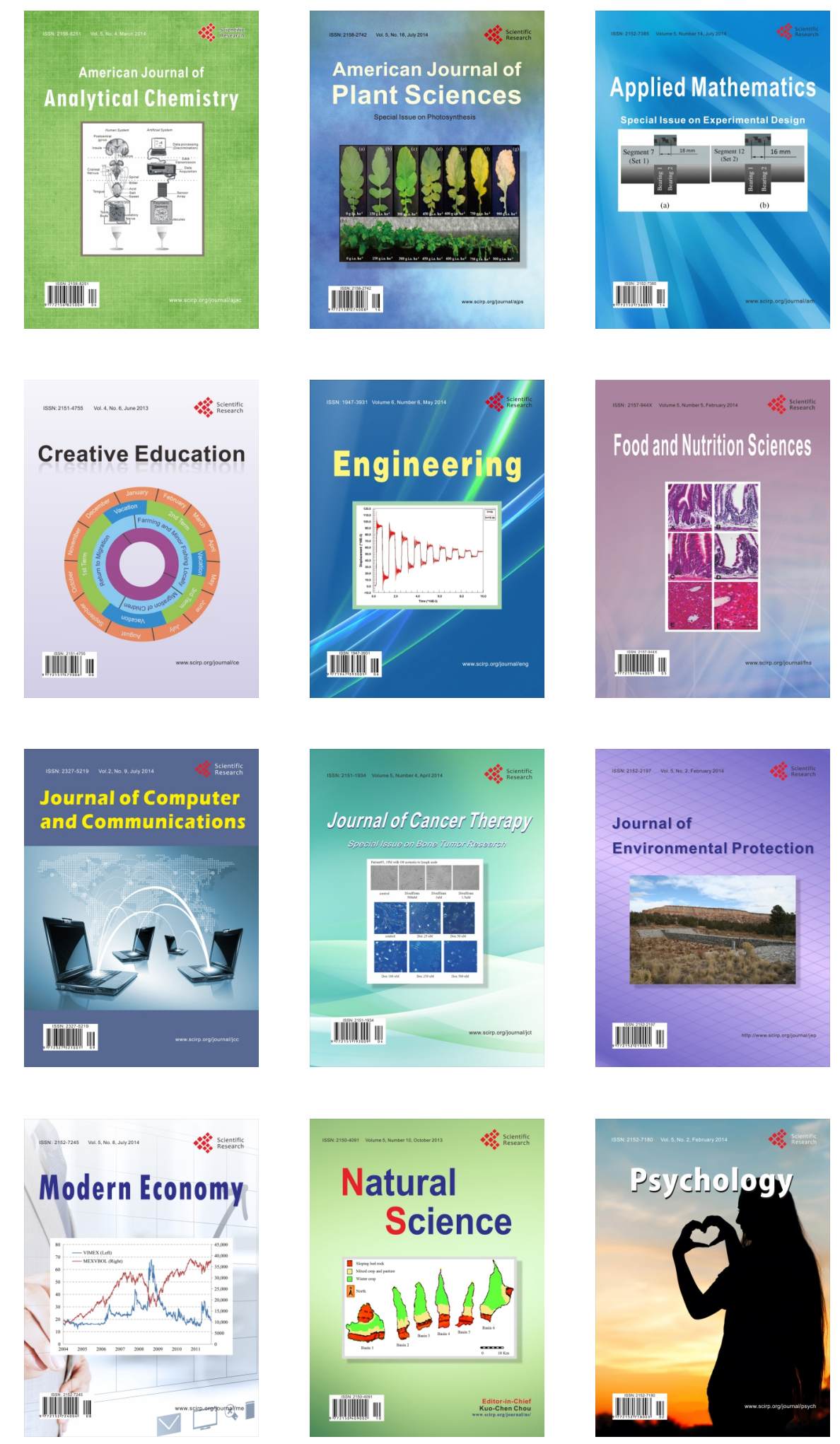